\title{
STEM-education in the mirror of sociological research
}

\author{
Oksana Buturlina, Tatyana Lysokolenko, Sergey Dovgal, Communal Institution of \\ Higher Education «Dnipro Academy of Continuing Education»
}

The article is devoted to the research of trends and mechanisms of STEM-innovations implementation in Ukraine. STEM - a series or sequence of educational programs designed to solve the problem of the scientific and engineering specialists lack for high-tech industries and raise the competitiveness of the state. It is a priority in state policy towards economy strengthening and state social order to the educational sector. Consequently, relevance of STEM in the modern European institutional space is beyond doubt. In this regard, attention is focused on measuring the understanding of STEM and its essence, on the prospects and difficulties of implementing these social technologies in Ukrainian realities. The paper presents the results of quantitative research conducted on the basis of author's methodologies, members of teaching staff, student youth, expert group and parents of high school students. On the basis of conducted monitoring results calculation, comparing the answers of different categories of respondents, the authors attempt to summarize the STEM technologies state in modern Ukrainian society and come to the conclusion that the implementation of relevant innovations contributes to the dissemination of dialogue among all participants in the educational process, parents and potential employers. Conducted research makes it possible to state the following. Educators of experimental educational institutions have a sufficiently high level of motivation to innovate, open to cooperation and understand the importance of innovations in the modern Ukrainian school. STEM topics of interest to students are clearly outlined. Therefore, the majorities of polled students support the STEM direction and understand its prospects but do not understand in what sphere and where they will work in the future, even choosing the STEM profession. The results of the study showed that modern parents are motivated to influence the future profession choice their own children. However, the direct parents' influence on the future profession choosing is limited because a significant number of high school students have their own opinion on this issue, which is in part or does not coincide, with parents. STEM innovations create a new space for a steady dialogue between educators, parents and employers for the development of the economies of the states and engage youth in STEM industry.

Keywords: society, innovation, education, strategy of education development in Ukraine, science, technology, engineering, monitoring

\section{STEM'-освіта в дзеркалі соціологічних досліджень}

\section{Оксана Бутурліна, Тетяна Лисоколенко, Сергій Довгаль, Комунальний заклад вищої освіти «Дніпровська академія неперервної освіти»}

Стаття присвячена дослідженню тенденцій та механізмів упровадження STEM-інновацій в Україні. Увага зосереджена на соціологічному дослідженні розуміння STEM-освіти і їі сутності, на перспективах i труднощах впровадження відповідних соціальних технологій в межах українських реалій. В роботі представлені результати кількісних досліджень, проведених на основі авторських методик, членів педагогічного колективу, учнівської молоді, експертної групи та батьків учнів старших класів. На основі отриманих результатів моніторингів, порівнюючи відповіді різних категорій респондентів, автори намагаються узагальнити стан STEM-технологій в сучасному українському суспільстві та приходять до висновку, що впровадження відповідних інновацій сприяє розвитку діалогу серед усіх учасників освітнього процесу, батьків і потенційних роботодавців. Проведені дослідження дозволяють констатувати наступне. Педагоги експериментальних навчальних закладів мають досить високий рівень мотивації до впровадження інновацій, відкриті для співпраці та розуміють важливість нововведень в сучасній українській школі. Опитані школярі в цілому підтримують впровадження STEM-інновацій, формуючи для себе пріоритетні напрямки, з якими пов'язують майбутню професію. При цьому, усвідомлюючи перспективність напрямку STEM, опитані учні не розуміють, в якій сфері та де вони можуть працювати в майбутньому, вибравши STEM-професію. Результати дослідження показали, що сучасні батьки зацікавлені в тому, щоб

${ }^{1}$ STEM (science, technology, engineering, mathematics) 
впливати на вибір майбутньої професії своїх дітей. Однак безпосередній вплив батьків на вибір майбутньої професії обмежений, оскільки у значної кількості старшокласників $є$ власна думка з цього питання, яка частково або повністю не збігається з думкою батьків. Проведені дослідження дозволяють стверджувати, що одним із найперспективніших напрямків упровадження STEM є об'єднання зусиль педагогів, роботодавців, учнів і сучасних батьків.

Ключові слова: суспільство, інновації, освіта, стратегія розвитку освіти в Україні, наука, технології, інженерія, моніторинг

\section{STEM-образование в зеркале социологических исследований}

\section{Оксана Бутурлина, Татьяна Лисоколенко, Сергей Довгаль, Коммунальное учреждение высшего образования «Днепровская академия непрерывного образования»}

Статья посвящена исследованию тенденций и механизмов внедрения STEM-инноваций в Украине. Внимание сосредоточено на измерении понимания STEM-образования и его сущности, на перспективах и трудностях внедрения этих социальных технологий в украинских реалиях. В статье представлены результаты количественных исследований, проведенных на основе авторских методик, членов педагогического коллектива, учащихся, экспертной группы и родителей учеников старших классов. На основе проведенного подсчета результатов мониторингов, сравнивая ответы разных категорий респондентов, авторы пытаются обобщить состояние технологий STEM в современном украинском обществе и приходят к выводу, что внедрение соответствующих инноваций способствует развитию диалога среди всех участников образовательного процесса, родителей и потенциальных работодателей. Проведенные исследования позволяют констатировать следующее. Педагоги экспериментальных учебных заведений имеют достаточно высокий уровень мотивации к внедрению инноваций, открыты для сотрудничества и понимают важность нововведений в современной украинской школе. Опрошенные школьники в целом поддерживают внендрение STEM-инноваций, формируя для себя приоритетные направления, с которыми связывают будущую профессию. При этом, осознавая перспективность направления STEM, опрошенные учащиеся не понимают, в какой сфере и где они могут работать в будущем, выбрав STEM-профессию. Результаты исследования показали, что современные родители заинтересованы в том, чтобы оказывать влияние на выбор будущей профессии своими детьми. Однако непосредственное влияние родителей на выбор будущей профессии ограничено, поскольку у значительного числа старшеклассников есть собственное мнение по этому вопросу, которое частично или полностью не совпадает с мнением родителей. Проведенные исследования позволяют утверждать, что один из самых перспективных способов внедрения STEM - это объединение усилий педагогов, работодателей, учащихся и современных родителей.

Ключевые слова: общество, инновации, образование, стратегия развития образования в Украине, наука, технологии, инженерия, мониторинг

Formulation of the problem.

$\mathrm{M}$ odern model of society progressive movement is formed under the influence of humanistic tendencies, which are represented in economic theory and economic practice. As a result, innovations that are focused on building human potential, one of which is STEM innovation, are spreading in education. Education Development Strategy presented by the World Bank Group focuses on addressing key triad of needs related to building the educational sector and expanding education opportunities for people such as: 'invest early' (Investearly), 'invest smartly' (Investsmartly), 'invest for all' (Investforall) [11]. Modern model of society progressive movement is formed under the influence of humanistic tendencies, which are represented in economic theory and www.grani.org.ua economic practice. As a result, innovations that are focused on building human potential, one of which is STEM-innovation, are spreading in education.

STEM - a series or sequence of educational programs designed to solve the problem of the scientific and engineering specialists lack for high-tech industries and raise the competitiveness of the state. It is a priority in state policy towards economy strengthening and state social order to the educational sector. Consequently, relevance of STEM in the modern European institutional space is beyond doubt.

However, today there is a certain dispersion of ideas, views, implementation directions of STEMinnovations. European countries have deferent initiatives for the STEM education implementation but all of them aimed at implementing policies in 
the following positions: development of scientific education for youth, ensuring wide awareness of the STEM industries development relevance, attracting young people to research in natural sciences and mathematics. The consequence is that today most countries have their own global approach to solve STEM issue at the national level: some have adopted national strategies, while others contribute to creation of specialized regional or local centers to improve the quality of teaching STEM subjects.

\section{Analysis of research and publications.}

Multivariety in directions of STEM realization and implementation can be considered a definite ontological theory that deserves attention and reflection in the Ukrainian public space. The European Schoolnet Academy experts state that national strategies for the introduction of STEM as innovation should be aimed at: creating a positive image of science, increasing the population's scientific literacy, improvement in the state of teaching and academic achievement at school, increasing students' interest in science, its popularization,overcoming gender stereotypes and achieving gender balance [12]. Current global STEM education models are based on the following common factors: reforming curricula, changing educational standards, establishing partnerships between schools, universities and employers, creating research centers for youth, innovation parks, STEM centers, STEM-ambassades, STEMlaboratories [7]. But, at the same time, STEMinnovation which is so rapidly moving in the sociopedagogical community, has been little discussed in business or industrioeconomic circles, and remains something like a 'black box' the content of which is not entirely clear.

With a wide range of directions, STEM research is the most diverse $[1 ; 2 ; 3 ; 4 ; 5 ; 10]$.

In Ukraine, despite the very young direction of STEM, the implementation programs have been developed at the government level for schools, universities, science centers (Letter Institute of Education Content Modernization 2015; Orders of the Ministry of Education and Science of Ukraine 2016, 2017) [6;8; 9].

In the other hand, STEM coalition of Ukraine brings together the efforts of the non-government sector (NGO, employers and other). Important role in the development of Ukrainian STEM education model is played by the efforts of scientists and practitioners who are trying to develop authorial technologies in the framework of experimental research at the national and regional levels. The data for this paper comes from the Regional Ukrainian project "STEM on the river Dnepr", which involves 41 educational centers in Dnipropetrovsk Region (secondary schools, scientific and technological lyceums, gymnasiums), STEM educators and partner organizations, representing regional industry. The main task of this STEM community is to build a unique regional innovative STEM education model, to develop young people's interest in STEM education and careers.

So, the first steps towards implementation of various STEM areas as innovation and education have already been made in the educational space. However, today members' of the European STEM coalition attention is focused on finding successful STEM implementation practices; the need for development of monitoring tools to assess effectiveness of various STEM activities is highly acute. Creating such an assessment system in the STEM area will allow caring out of comparative studies in the future.

\section{The presentation of the main material.}

Purpose of the article is to summarize the results of conducted sociological research, determine the specificity and features of STEM introduction as a topical modern innovation in Ukraine (on the example of Dnipropetrovsk region). Continuing the approaches proposed by European researchers (Kudenko, Gras - Velázquez). in the inGenius project, we expanded the scope of the study and involved groups of reference people who influence the choice of a profession by young people. These are parents, teachers and experts of the region, representing different communities. The results presented in this paper can be useful for educators who are trying to build their own new model of education and solve the problems of promoting professions among young people.

\section{Analysis of the results}

\section{I. 'PEDAGOGICAL WORKERS'} MOTIVATIONAL AND TECHNOLOGICAL READINESS FOR EXPERIMENTAL WORK ON INTRODUCTION OF THE STEMEDUCATION INNOVATIVE MODEL IN DNIPROPETROVSK REGION'

It should be noted that the study of teachers' opinion was very important because STEM as a direction came to Ukraine first of all through the education system, the most massive - through the school, and teachers, in this case act as agents of change, from whose thoughts and guidelines further development of STEM-innovations in Ukraine is largely dependent. 


\section{General characteristics of conducted research}

\begin{tabular}{|c|c|c|c|c|}
\hline Respondents & $\begin{array}{c}\text { Numb } \\
\text { er of } \\
\text { respo } \\
\text { ndent } \\
\text { s }\end{array}$ & Purpose of the poll & Method & Dates \\
\hline $\begin{array}{l}\text { Principals, } \\
\text { coordinators and } \\
\text { teachers of } \\
\text { experimental schools }\end{array}$ & 230 & $\begin{array}{l}\text { Purpose of the study was to identify } \\
\text { the level of motivation and } \\
\text { technological readiness of } \\
\text { pedagogical workers for } \\
\text { experimental work on the } \\
\text { introduction of STEM education } \\
\text { innovative model in regional } \\
\text { secondary education institutions }\end{array}$ & $\begin{array}{c}\text { On-line } \\
\text { pollwith } \\
\text { google-form } \\
\text { service } \\
\text { (author'squest } \\
\text { ionnaire) }\end{array}$ & $\begin{array}{l}\text { April } \\
2017\end{array}$ \\
\hline $\begin{array}{l}\text { 10th form pupilsof } \\
\text { Dnipropetrovsk } \\
\text { region general } \\
\text { education institutions }\end{array}$ & 670 & $\begin{array}{l}\text { Purpose of the research was to } \\
\text { investigate students' public opinion } \\
\text { about studying subjects and selecting } \\
\text { STEM-professions }\end{array}$ & $\begin{array}{l}\text { On-line poll } \\
\text { with google- } \\
\text { form } \\
\text { service(autho } \\
\text { r'squestionnai } \\
\text { re ) }\end{array}$ & $\begin{array}{l}\text { October } \\
2017\end{array}$ \\
\hline $\begin{array}{l}\text { Expert Group: } \\
\text { Management of } \\
\text { leading enterprises of } \\
\text { Ukraine; } \\
\text { Employees of higher } \\
\text { educational } \\
\text { institutions } \\
\text { Ukraine; } \\
\text { The heads of local } \\
\text { education authorities; } \\
\text { Representatives of } \\
\text { employment centers }\end{array}$ & 40 & $\begin{array}{l}\text { Purpose of the survey is to study the } \\
\text { experts' opinions of different } \\
\text { categories on the main problems and } \\
\text { perspectives of introducing STEM- } \\
\text { education at the regional level (on } \\
\text { the example of Dnipropetrovsk } \\
\text { region). }\end{array}$ & $\begin{array}{l}\text { On-line poll } \\
\text { with google- } \\
\text { form service } \\
\text { (author'squest } \\
\text { ionnaire) }\end{array}$ & $\begin{array}{l}\text { April } \\
2018\end{array}$ \\
\hline $\begin{array}{l}\text { Parents of high school } \\
\text { students }\end{array}$ & 486 & $\begin{array}{l}\text { Purpose of the survey is to study the } \\
\text { level of parents' influenc on the } \\
\text { professional orientation of senior } \\
\text { students. }\end{array}$ & $\begin{array}{l}\text { On-line poll } \\
\text { with google- } \\
\text { form service } \\
\text { (author'squesti } \\
\text { onnaire) }\end{array}$ & $\begin{array}{l}\text { October } \\
2018\end{array}$ \\
\hline
\end{tabular}

Conducted questionnaire allows assuming the following. Interviewed representatives of experimental educational institutions generally have a positive attitude towards innovation, but provided that it will be aimed at working with students, introduction of new forms and methods of work. In general, it can be stated that surveyed educators are ready to implement changes related to the implementation of innovations.

Innovations implementation in any sphere of human life is always associated with a variety of difficulties. Among the reasons that may slow the introduction of new pedagogical ideas and technologies, the respondents highlight, first of all, insufficient material provision - $(33 \%)$, conservatism in education - $(16 \%)$, excessive saturation of educational material - (14\%), hasty introduction of new in the process of training $(12 \%)$, lack of personal time for the implementation of innovations - $(13 \%)$. Also, attention is drawn to the fact that only $6 \%$ of the respondents identified among the reasons that hinder innovation activity, students' psychological unwillingness to perceive innovations.

Similar survey results may indicate the readiness of students themselves to perceive new pedagogical ideas and technologies in education, but among the main reasons that impede their implementation are material provision, educational prograimperfections and teachers' overload. (Chart № 1).

Respondents were given an opportunity to determine their vision of what factors could affect the successful implementation of STEM education in their institution. (Chart № 2).

Such respondents' position may indicate a lack of understanding of potential employers and government bodies' role in the STEM education implementing process.

The vast majority of surveyed educators $(85 \%)$ are convinced that introduction of STEM education will improve the quality of education at their institution. It is clear that STEM-education 
in educational institutions can be realized only in specific areas of study, since this concept includes application of science, technology, engineering, mathematics in the educational process. In this study, respondents were asked to decide on exactly which areas STEM education could be carried out at their institution. Most respondents noted that in their educational institution STEM education can be carried out in the following areas: computer technologies $(28 \%)$, natural sciences $(27 \%)$ and mathematics (26\%). A much smaller number of respondents noted that in their educational institution STEM education could be applied in areas such as biology and compatible sciences $(12 \%)$ and traditional engineering $(5 \%)$. It should be noted that traditional engineering is one of the STEM education key areas but as we see from the survey results, educational institutions are not ready for this direction development today because they do not have appropriate material base.

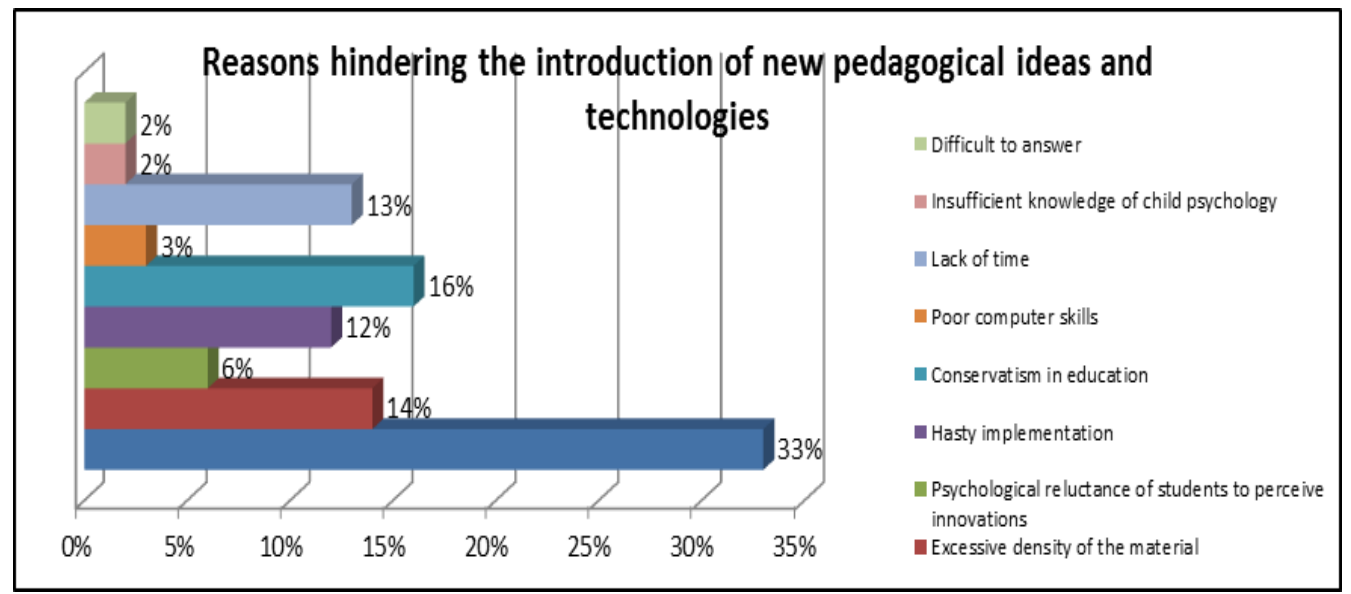

Chart № 1. 'Reasons hindering the introduction of new pedagogical ideas and technologies'

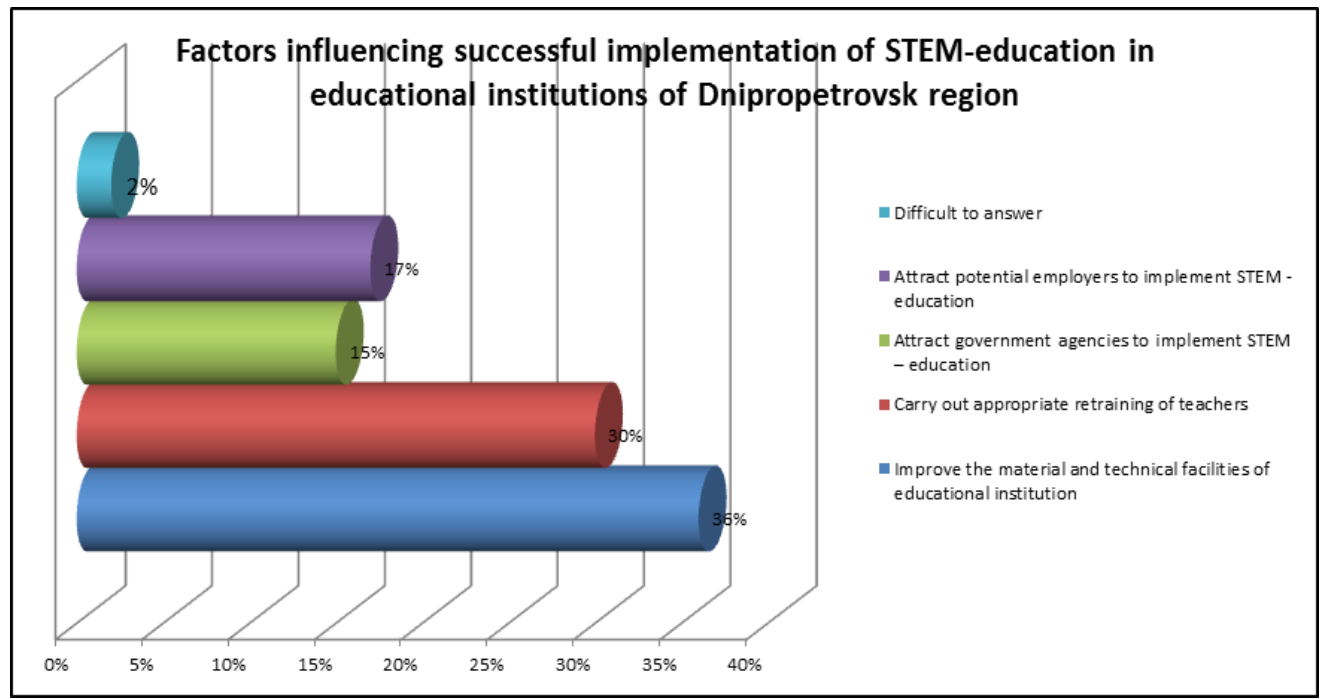

Chart № 2. 'Factors influencing successful implementation of STEM-education in educational institutions of Dnipropetrovsk region'

The survey on which class should be STEMeducation implemented from in Dnipropetrovsk region educational institutions showed interesting results. Thus, the vast majority of respondents $(70 \%)$ believe that STEM-education should be introduced in elementary school (grades 1-4) already. Only 5\% of respondents noted that STEM-education should be introduced from high school (grades 9-11). Almost a third of respondents (23\%) believe that STEMeducation should be introduced in grades 5-9.

Conducted research makes it possible to state the following. Educators of experimental educational 
institutions have a sufficiently high level of motivation to innovate, open to cooperation and understand the importance of innovations in the modern Ukrainian school. This is partly due to possibilities of creative self-realization for both teacher and student, an opportunity to increase students' curiosity towards different school subjects and so on. At the same time, understanding the importance of innovations, surveyed teachers have some concerns about their implementation. Concerns related to insufficient material provision, conservatism in education, overload of educational material, etc.

The study suggests that the vast majority of respondents do not fully understand the peculiarities and prospects of school's interaction with potential employers. This may indicate a narrower understanding of STEM-education nature that is perceived by educators only as part of school's educational environment for the child and teacher. At the same time, other potential perspectives from realization of the directions of STEM-education were almost not taken into account by the respondents. Respondents consider computer technologies, natural sciences and mathematics the most favorable areas for implementing STEM-education in school. Moreover, engineering and robotics remain underestimated. Perhaps this is connected, on the one hand, with a low level of material and technical base of educational institutions, on the other hand - with a narrow view of the possibilities of integration of different directions of STEMeducation into the school's educational process. We emphasize integration itself, because it is this way of implementing STEM-education at school, according to respondents, is a priority.

Also, a sociological survey allows to state that experimental educational institutions need assistance in the form of a thorough education, which can be implemented as a cross-cutting component of the forms chosen by respondents. Such education should be related to the explanation of the possibilities of integrating various areas of STEM education into the educational process of the school, explaining the significance of the effective implementation of STEM education in school as an integral part of a successful student's personality, and in the future a graduate of an adult school, since STEMeducation has a large number of opportunities for implementing a competent approach in school.

II. 'STUDYING THE ATTITUDE OF 10TH GRADE STUDENTS TO THE STUDY OF SUBJECTS AND SELECTION OF STEM PROFESSIONS'

Survey results make it assumable that the polled 10th grade students are interested in different directions of STEM - education. (Chart № 3)

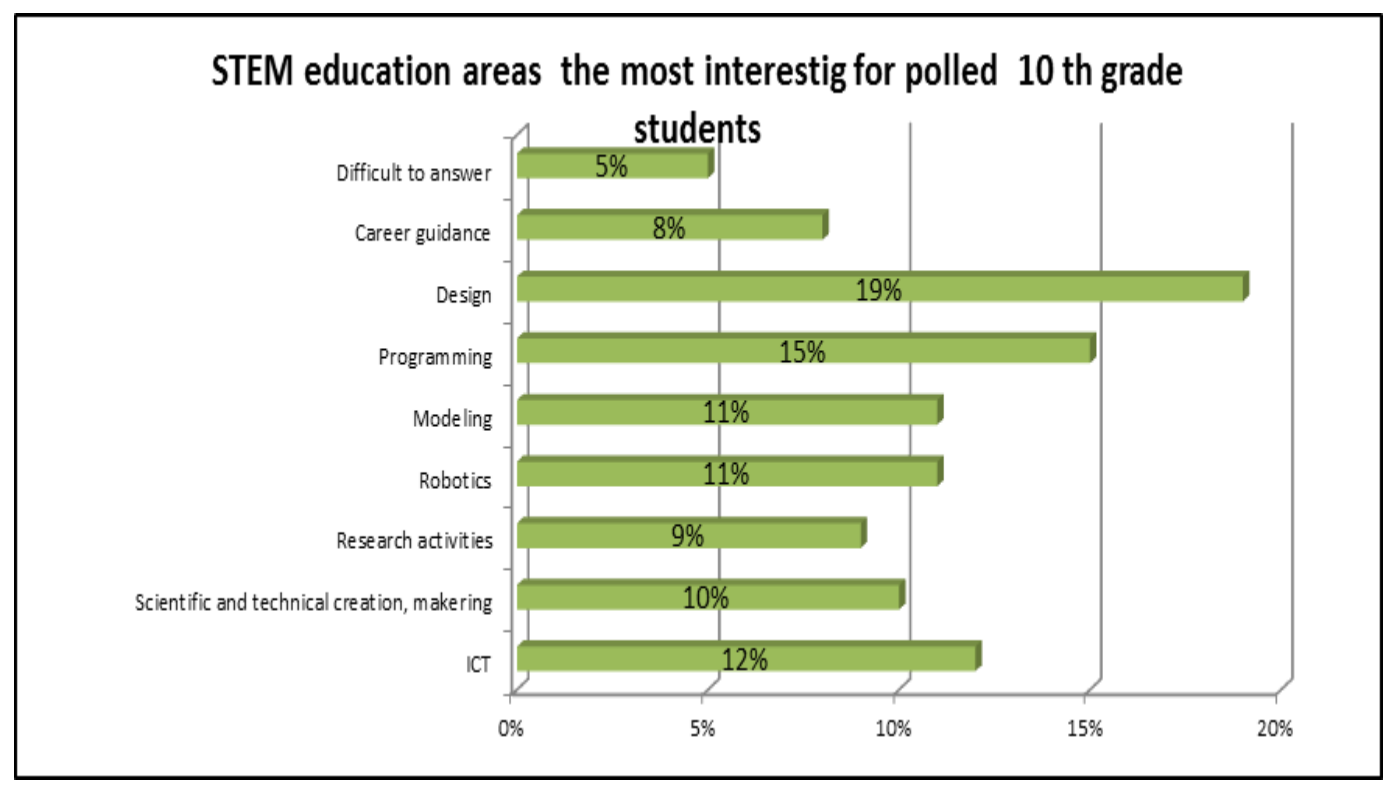

Chart № 3. 'STEM education areas the most interestig for polled 10 th grade students' 
Vast majority of polled students (92\%) fully agree that in the nearest future society will need specialists in STEM fields (scientists, technologists, engineers, etc.). $74 \%$ of 10 th grade students would like to learn more about STEM professions while studying at school.

As shown by the research results, natural, mathematical disciplines and technological education are not very interesting for the questioned children. So, only the third of respondents $(25 \%)$ noted that these are the most beloved subjects. Most respondents (almost 38\%) are interested in these particular directions of education not more than other. At the same time $14 \%$ state that there would be a greater interest in natural and mathematical disciplines, but everything depends on the teacher's level of training. It was categorically noted that these subjects are remarkably difficult and they do not want to study by $14 \%$ of those polled. Absolutely do not want to learn $5 \%$ of those polled. $4 \%$ of the respondents are not determined on the question. (Chart № 4).

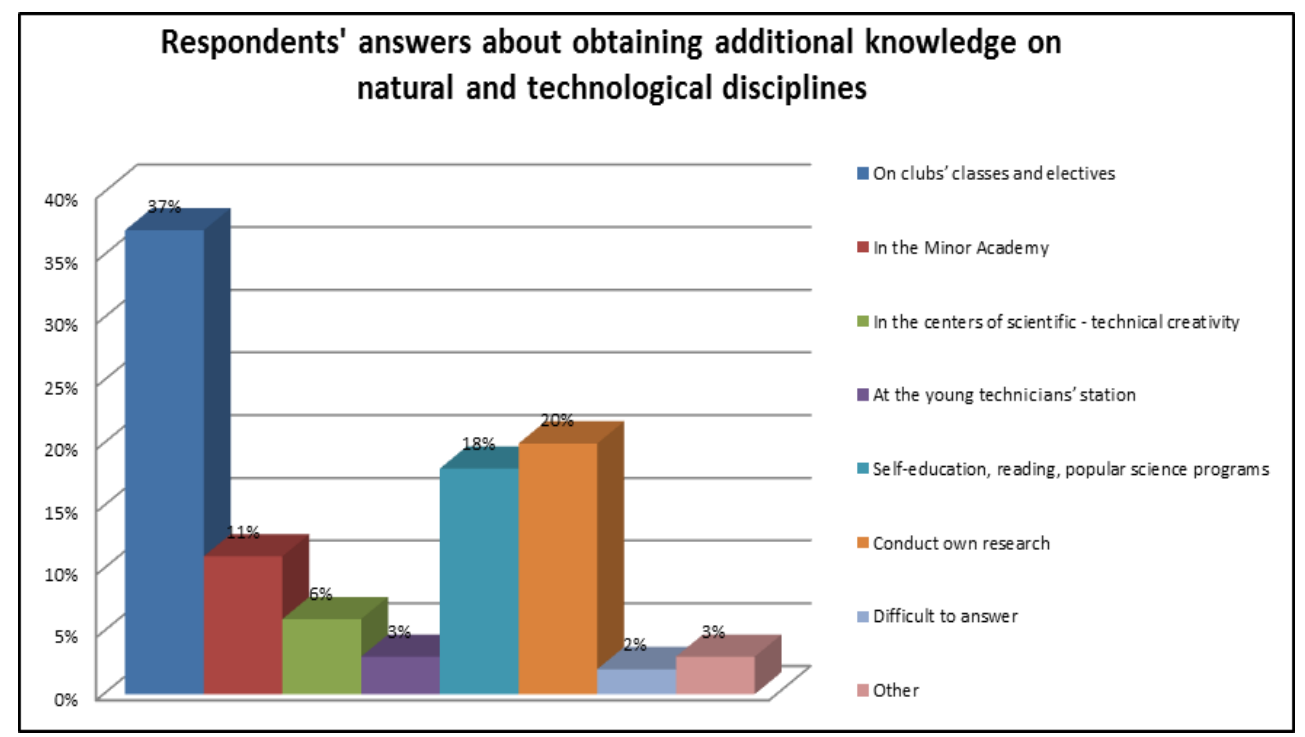

Chart № 4. 'Respondents' answers about obtaining additional knowledge on natural and technological disciplines'

However, the questionnaire showed that only $25 \%$ of respondents indicated they could choose STEM-professions like industries related to natural sciences, technologies and mathematics. At the same time, respondents (29\%) said that they would like to choose a profession in the industry, but do not know where they would be able to work in the future. One-fourth of respondents $(25 \%)$ noted that they lacked sufficient knowledge of natural sciences and mathematics and could not choose a profession in the field of STEM. Also $10 \%$ of respondents noted that in their opinion this direction is not promising.

Let's dwell on the poll results concerning the students' thoughts about choice of future profession and the forms of career guidance.

The questionnaire results showed that majority of poll participants $(58 \%)$ have already decided on their future career choice, and $29 \%$ - have not. Difficult to answer - $12 \%$.

The vast majority of polled 10th grade students believe that a person can decide on the choice of future profession while studying at a general education institution. Thus 55\% noted that it is possible to determine the choice of future profession while studying in the 10th form. At the same time $20 \%$ of the respondents consider it's normal to determine their future profession choice in the 11 th form and $13 \%$ believe that it is possible during studying in the 5-7 form. Only 2\% of respondents believe that the future profession can be chosen only before entering the university or college. $6 \%$ of respondents are not determined on the given question.

Respondents in the 10th grade did not identify the professional orientation tools, which contribute to the future professional choice. (Chart № 5).

Among the criteria that influence the choice of future profession and directions of training respondents distinguish the following. (Chart № 6).

Conducted research gives the ability to establish the following. STEM topics of interest 
to students are clearly outlined. The vast majority of respondents in the 10th grade would like to learn more about the world of STEM-professions while studying at school.10th grade students interested in natural and technological disciplines are studying not only in school, but also attend additional classes and carry on individual work. Although most 10th grade respondents agree that knowledge of mathematics, natural sciences and technology is needed for successful career in the future, not all of them have the appropriate skills and qualities required to work in these areas. Therefore, the level of interest among students in the study of subjects of natural, mathematical and technological cycles is sufficiently high, but it is entirely natural that not all of them have the appropriate skills and inclinations for this sphere. And this was just one of the problems existing in the process of studying the subjects of natural, mathematical and technological cycles and consequently, in the process of STEM
- education implementation. Another problem is that only a small part of the respondents choosing a branch related to natural sciences, technology and mathematics clearly understand in what sphere and where they will work in their further life. Therefore, the majority of polled GEI students support the STEM direction and understand its prospects but do not understand in what sphere and where they will work in the future, even choosing the STEM profession. Survey results showed that the majority of respondents in the 10th grade today have already determined the future profession choice. Therefore, the majority of respondents believe that a person can determine the future profession choice during studying at GEI. But the part of respondents noted that they still need help in choosing the future profession. At the same time, polled 10th grade students did not define the professional orientation tools, which can help their future profession choice.

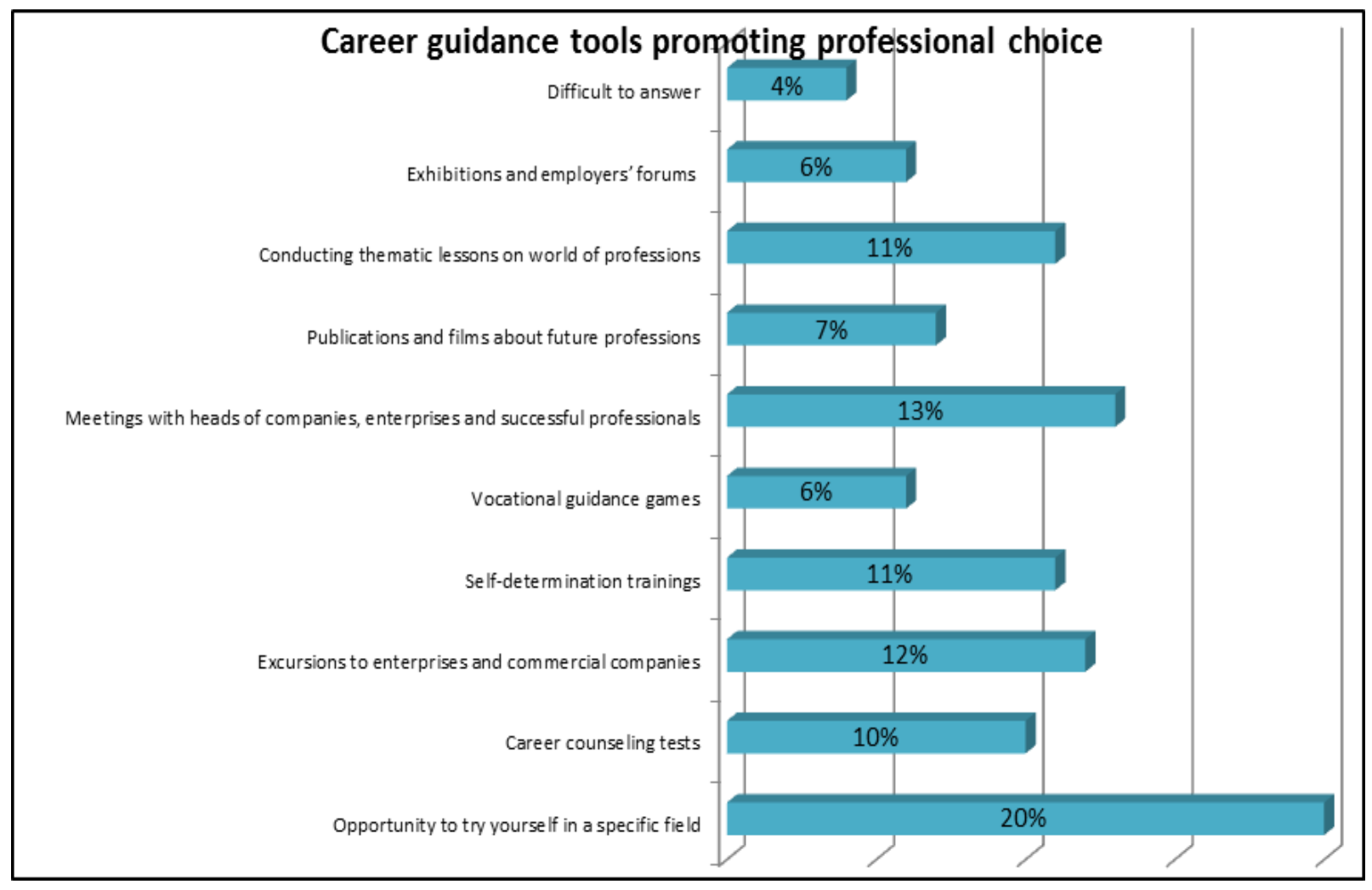

Chart № 5. 'Career guidance tools promoting professional choice' 


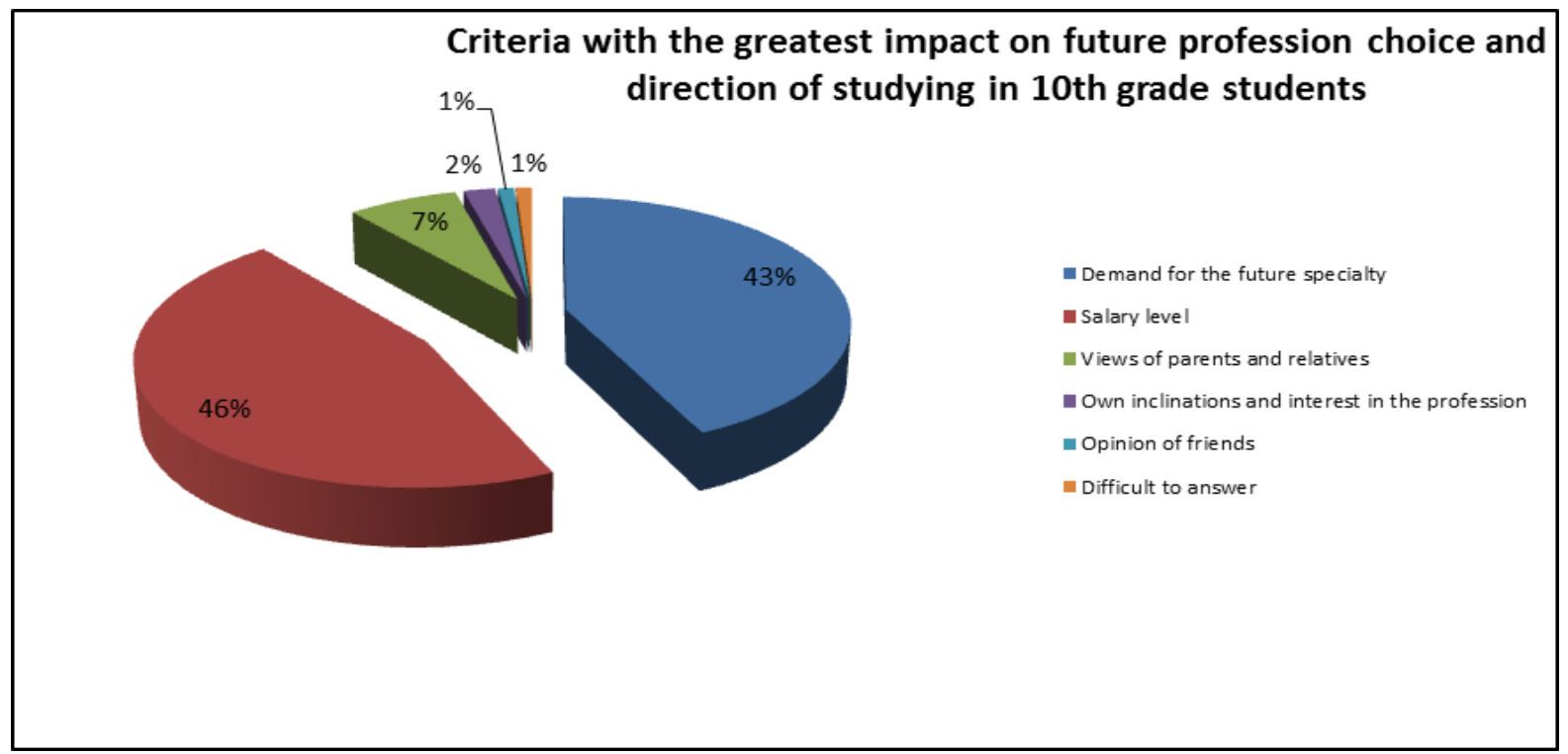

Chart № 6. 'Criteria with the greatest impact on future profession choice and direction of studying in 10th grade students'

III. 'PROBLEMS AND PROSPECTS OF STEM-EDUCATION IMPLEMENTATION IN DNIPROPETROVSK REGION' (expert survey)

Monitoring of expert opinions was seen relevant not only to examine the opinions of various specialists regarding the complexity of STEM education implementation, but also to attract their attention to these innovations, determine the level of readiness of different society layers and their representatives to solve professional orientation problems. The study of expert opinion on problems and means of overcoming STEM personnel deficit in various areas of professional activity, identifying the most in-demand STEM specialty, suggests the following. Today there is a shortage of STEM personnel. Experts believe that the most promising ways to overcome this deficit are: establishment of cooperation between school, university and enterprises ( $21 \%$ of respondents supported this position); introduction of joint projects with employers $(17 \%$ of respondents supported this position), updating of school and university curricula (16\% of respondents supported this position). That, in turn, confirms the prospect of certain directions of reforms in education. At the same time, insufficient methods of solving qualified employees lack problem according to experts are the following: support of the promising youth by employers ( $12 \%$ of respondents supported this position) and introduction of dual education (13\% of respondents supported this position). It can be assumed that such percentage rate is related with regulatory norms of this work, insufficient distribution of these support forms and lack of awareness in employers about such involvement of young people to work in their companies / enterprises. The vast majority of experts believe that modern education should be based on close interaction between general education institutions, higher educational institutions, enterprises (various forms of ownership), local self-government bodies for the training of skilled labor in the labor market. $58 \%$ of those polled fully agree with this statement and only $39 \%$ partially support the idea. $3 \%$ of the respondents have not decided on the answer to the question. (Chart № 7).

The study of supporting mechanisms for promising pupils and students by potential employers demonstrated the following. $40 \%$ of respondents believe that young people may be determined on the choice of profession while studying in grades 10-11. Respondents believe that one of the most important criteria for choosing the future specialty is the level of wages $(35 \%$ of respondents supported the position), inclinations and interests of youth $(26 \%$ of respondents supported the position), demand for the future specialty (17\% of respondents supported the position). Interestingly in previous studies youth's (pupils) responses to this question were distributed as follows: more important for young people in choosing the future profession is the level of wages $(46 \%)$ and the demand for future specialty $(43 \%)$. Also, taking into account different areas of work, experts' opinions were unevenly divided on the questions about career support tools: $15 \%$ of 
respondents identified excursions to enterprises, $14 \%$ - meetings with business leaders, $10 \%-$ employers' forums. It should be noted that answers of previously polled senior students are similar to the experts' opinion. Attention is drawn to the fact that neither students nor experts have formed a dominant position in responding to this question. The vast majority of experts are ready to organize practices for pupils and students ( $76 \%$ of respondents supported the position). $42 \%$ of respondents are sure that students' involvement to the internship is the most effective form of support for promising youth. However, none of respondents pointed out that the statutory could entirely or partially pay the cost of training. Instead, $14 \%$ of those polled experts tend to the fact that introduction of grants and $12 \%$ introduction of scholarship are effective forms of supporting talented youth.

Accordingly, it can be assumed that the selected expert group as a whole has its own vision of how to promote the STEM education brand in the Ukrainian society.

\section{Experts ' answers to the question: Should modern education be based on close cooperation between GEls, universities, enterprises and local authorities in order to train skilled emploees in the labor market?}

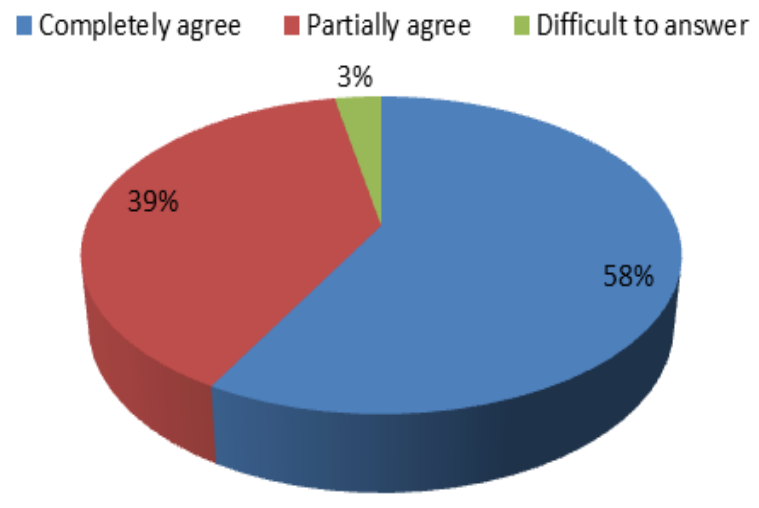

Chart № 7. 'Experts' answers to the question: Should modern education be based on close cooperation between GEIs, universities, enterprises and local authorities in order to train skilled employees in the labor market?'

The study of supporting mechanisms for promising pupils and students by potential employers demonstrated the following. $40 \%$ of respondents believe that young people may be determined on the choice of profession while studying in grades 10-11. Respondents believe that one of the most important criteria for choosing the future specialty is the level of wages $(35 \%$ of respondents supported the position), inclinations and interests of youth (26\% of respondents supported the position), demand for the future specialty $(17 \%$ of respondents supported the position). Interestingly in previous studies youth's (pupils) responses to this question were distributed as follows: more important for young people in choosing the future profession is the level of wages $(46 \%)$ and the demand for future specialty $(43 \%)$. Also, taking into account different areas of work, experts' opinions were unevenly divided on the questions about career support tools: $15 \%$ of respondents identified excursions to enterprises, $14 \%$ - meetings with business leaders, $10 \%-$ employers' forums. It should be noted that answers of previously polled senior students are similar to the experts' opinion. Attention is drawn to the fact that neither students nor experts have formed a dominant position in responding to this question. The vast majority of experts are ready to organize practices for pupils and students $(76 \%$ of respondents supported the position). $42 \%$ of respondents are sure that students' involvement to the internship is the most effective form of support for promising youth. However, none of respondents pointed out that the statutory could entirely or partially pay the cost of training. Instead, $14 \%$ of those polled experts tend to the fact that introduction of grants and $12 \%$ introduction of scholarship are effective forms of supporting talented youth. 
Accordingly, it can be assumed that the selected expert group as a whole has its own vision of how to promote the STEM education brand in the Ukrainian society.

IV. 'THE INFLUENCE OF PARENTS ON PROFESSIONAL ORIENTATION OF HIGH SCHOOL STUDENTS'

STEM - innovations is an area of activity that is directly related to the professional orientation of modern youth, which is why, in the context of the development of dialogue in the modern Ukrainian educational space, it is important to focus on the opinion of the parents of students of experimental educational institutions.

The survey showed that the vast majority of questioned parents (92\%) discussed the problem of choosing a future profession with their children; only $(4 \%)$ of respondents indicated that they did not discuss this problem with their children and (4\%) of respondents are not determined on the given question.

The research also demonstrated that parents' thoughts about choosing a future profession often coincide with the child's view. Thus, this was indicated by $(42 \%)$ of the interviewed respondents. While $40 \%$ of parents surveyed said their opinion on the choice of future occupation was only partially equivalent to their child's opinion. Along with this $14 \%$ of respondents noted that their opinion does not completely coincide with the opinion of their own child. $4 \%$ of respondents are not determined on the given question, respectively.
Among the areas of professional activity in which respondents advise to apply the skills of high school students, it is possible to single out, first of all, information technologies $(27 \%)$, medicine $(11 \%)$, administrative activities (10\%), production (9\%), science $(9 \%)$, art $(7 \%)$, pedagogy $(7 \%)$, sphere of service $(7 \%)$, sports $(5 \%)$, military affair $(3 \%)$.

Among the main criteria that influence the choice of specialty for high school students, the respondents emphasize: the level of wages $(33 \%)$, the demand for the future specialty $(30 \%)$, the tendency and interest in the specialty for children (30\%). Only $(3 \%)$ of respondents noted that among the suggested criteria, the opinions of parents and relatives and the opinion of friends (3\%). (1\%) of respondents are not determined on the given question.

It should be pointed out that according to the sociological survey «Studying the attitude of 10th grade students to the study of subjects and selection of STEM professions», which was held in October 2017 among the criteria that influence the choice of the future profession and areas of study, the students interviewed singled out, first of all: the level of payment labor $(46 \%)$ and the demand for a future specialty (43\%). (see Chart № 6).

Thus, the answers of the parents interviewed regarding the criteria influencing the choice of future profession by the high school students confirm their low level of influence on the choice of future profession by the student youth. The same opinion is shared by the high school students themselves and their parents. (Chart № 8)

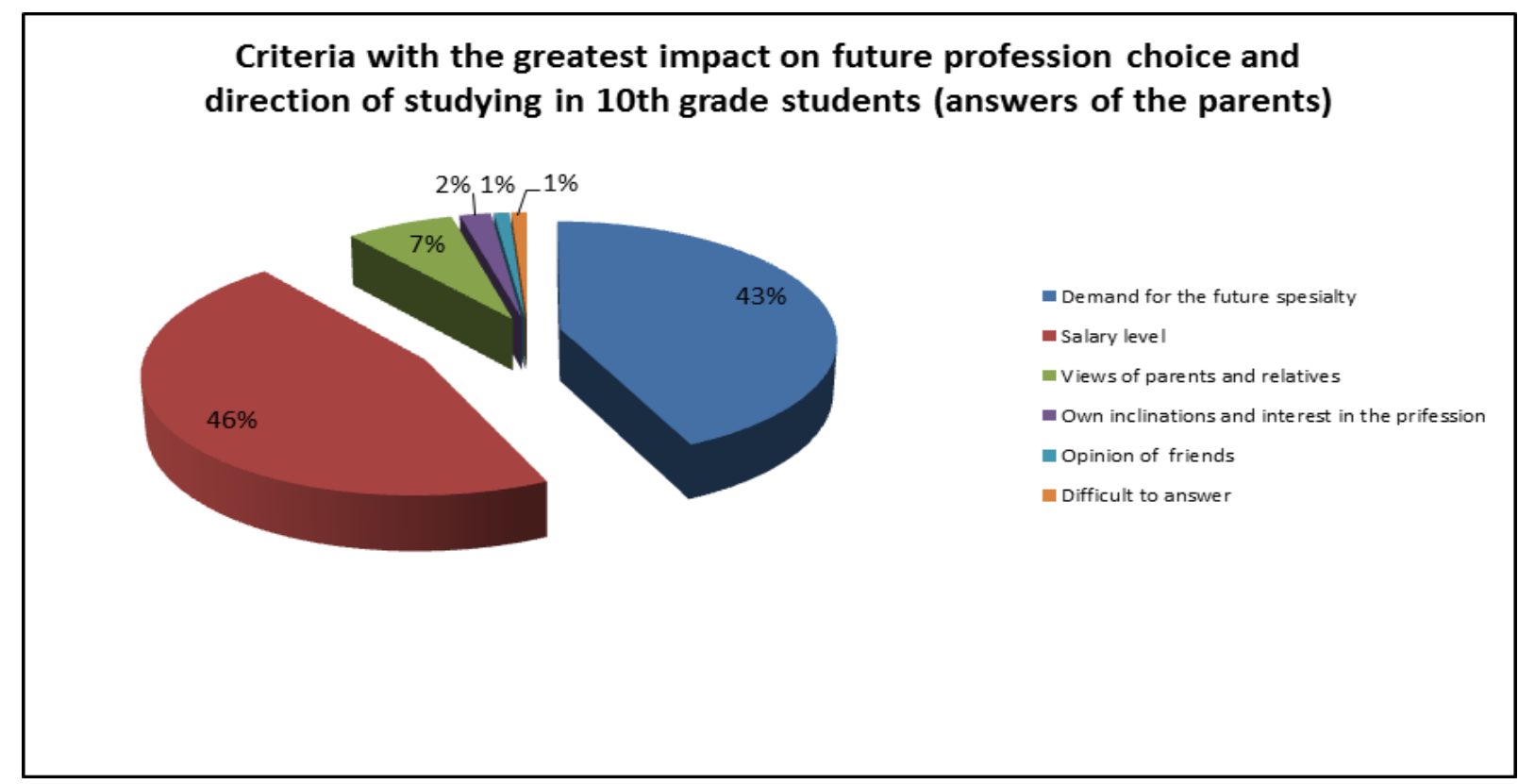

Chart № 8. 'Criteria with the greatest impact on future profession choice and direction of studying in 10th grade students (answers of the parents)' 
Thus, the results of the study showed that modern parents are motivated to influence the choice of the future profession of their own children. However, the direct influence of parents on the process of choosing the future profession of their children is limited because a significant number of high school students have their own opinion on this issue, which is in part, or does not coincide, with parents.

\section{Conclusions.}

Consequently, the study made it possible to form a general conceptual vision of prospects for introduction of various STEM areas in Ukraine on the example of Dnipropetrovsk region. Taking into account the diversity of carried out monitorings, the willingness of teachers, students and experts to innovation related to STEM sphere is highly positive. However, each group of respondents has its difficulties and concerns about implementation and promotion of STEM brand. Thus, in general, teachers are concerned about weak material and technical base of schools and not all have full confidence in their own knowledge and skills needed for full implementation of STEM education. As for the students, it is necessary to point out that there are problems with interest of students to natural and mathematical sciences, there is no established view of students on interesting or preferable forms of career guidance in the choice of future profession. Salaries and demand on the labor market and not students' interest remain dominating in future career choice. The poll allowed to see some differences between the perceptions of what is a STEM school and what is STEM occupations in adulthood.

The parents' survey showed that this group of respondents is interested in the process of choosing their child's future profession, but they have no significant influence on the final decision of their own children. Also, this monitoring assured that the most reliable way to implement STEM is to unite the efforts of educators, employers, students and modern parents.

STEM innovations create a new space for a steady dialogue between educators, parents and employers for the development of the economies of the states and engage youth in STEM industry.

\section{REFERENCES}

1. Belland, B.R.,Walker, A.E., Kim, N.J., \& Lefler, M. (2017). «Synthesizing results from empirical research on computer-based scaffolding in STEM education: A meta-analysis». Review of Educational Research, 87 (2), $309-344$. 2. Caprile, M., Palmé, R., Sanz, P., \& Dente, G. (2015). "Encouraging STEM Studies for the Labour Market". Report. European Parliament. Retrieved from: http:// www.europarl.europa.eu/RegData/etudes/STUD/2015/542199/IPOL_ STU(2015)542199 EN.pdf

3. Coleman, N., Farina, D.M., Rabinovich, L. (2017). "Common denominators to learner-centered success: Undergraduate STEM, graduate teacher education, and an educational technology doctoral program". Handbook of research on learner-centered pedagogy in teacher education and professional development. DOI: 10.4018/978-15225-0892-2.ch002

4. Kelley, T., \& Knowles, G. (2016). “A conceptual framework for integrated STEM education“. International Journal of STEM Education, 3-11. DOI: https://doi.org/10.1186/s40594-016-0046-z

5. Kudenko, I. \& Gras-Velázquez, A. (2016). "The future of European STEM workforce: What Secondary School Pupils of Europe Think About STEM Industry and Careers". Insights from Research in Science Teaching and Learning: Selected Papers. Switzerland: Springer International Publishing.

6. Instytut modernizatsiyi zmistu osvity (IECM) «Pro zaprovadzhennya napryamiv STEM-osvity» [Letter Institute of Education Content Modernization (IECM) "On introduction of directions of STEM-education"7, 2.1, 10-14. (2015). Retrieved from: https://drive.google.com/file/d/0B3m2TqBM0APKd2tFMXVtZU96NzA/view [in Ukrainian].

7.Marginson, S., Tytler, R., Freeman, B., \& Roberts, K. (2013). STEM Country Comparisons. Report for the Australian Council of Learned Academies. Australian Council of Learned Academies, Melbourne. Retrieved from: https://www.acola.au

8. Nakaz Ministerstva osvity i nauky Ukrayiny «Pro stvorennya robochoyi hrupy z vprovadzhennya steblovoyi osvity $v$ Ukrayini» [Order of the Ministry of Education and Science of Ukraine "On the Establishment of a Working Group on the Implementation of Stem-Education in Ukraine"], 188. (2016). Retrieved from: https://drive.google.com/file/ d/0B3m2TqBM0APKSG1MMXREeVFpNDg/view [in Ukrainian].

9. Nakaz Ministerstva osvity i nauky Ukrayiny «Pro provedennya naukovo-doslidnoyi roboty na ukrayins'komu rivni na temu: Naukovo-metodychni zasady stvorennya ta funktsionuvannya Vseukrayins'koho naukovo-metodychnoho virtual'noho STEM-tsentru na 2017 rik 2021» [Order of the Ministry of Education and Science of Ukraine "On conducting research and experimental work at the Ukrainian level on the theme: Scientific and methodical principles of creation and functioning of the All-Ukrainian scientific and methodological virtual STEM-center for 2017-2021 "], 708. (2017). Retrieved from: https://drive.google.com/file/d/0B3m2TqBM0APKaXJGVlk1bVZ2cFk/view [in Ukrainian]. 
10. Peterson, A., Gaskill, M., \& Cordova, J. (2018). Connecting STEM with Social Emotional Learning (SEL) Curriculum in Elementary Education. In Society for Information Technology \& Teacher Education International Conference, 1212-1219. Retrieved from: https://www.learntechlib.org/primary/p/182681.

11. Quality training for all (QTFA). "Investments in knowledge and skills to promote development in the education sector of the World Bank Group for the period until 2020“. Retrieved from: URL:http:/www.siteresources.worldbank. org/EDUCATION/Resources/ESSU/463292 1306181142935/Russian_Exec_Summary_2020_FINAL.pdf.

12. Wynarczyk, P., \& Hale, S. (2009). Improving take-up of science and technology subjects in schools and colleges: A synthesis review. Newcastle: Newcastle University.

\section{Бутурліна Оксана Василівна}

Канд. філос.н., доцент

Комунальний заклад вищої освіти «Дніпровська академія неперервної освіти» 49006, Дніпро, вул. В. Антоновича, 70

\section{Buturlina Oksana}

$\mathrm{PhD}$, Assoc. Prof.

Communal Institution of Higher Education «Dnipro Academy of Continuing Education» 70, Antonovicha str., Dnipro, 49006, Ukraine

Email: buturlina71@gmail.com

ORCID 0000-0002-9603-4752

\section{Лисоколенко Тетяна Володимирівна}

Канд. філос.н., доцент

Комунальний заклад вищої освіти «Дніпровська академія неперервної освіти» 49006, Дніпро, вул. В. Антоновича, 70

Email: lusokolenko@gmail.com

ORCID 0000-0003-1545-8682

\section{Lysokolenko Tatyana}

$\mathrm{PhD}$, Assoc. Prof.

Communal Institution of Higher Education «Dnipro Academy of Continuing Education» 70, Antonovicha str., Dnipro, 49006, Ukraine

\section{Довгаль Сергій Анатолійович}

Канд. філос.н., доцент

Комунальний заклад вищої освіти «Дніпровська академія неперервної освіти» 49006, Дніпро, вул. В. Антоновича, 70

\section{Dovgal Sergey}

$\mathrm{PhD}$, Assoc. Prof.

Communal Institution of Higher Education «Dnipro Academy of Continuing Education»» 70, Antonovicha str., Dnipro, 49006, Ukraine

Email: sdovgal2010@gmail.com

ORCID 0000-0002-7134-7488

Цитування: Бутурліна О. В. Особливості розробки процедурного плану для аналізу дискурсу мусульман в українській пресі / О. В. Бутурліна, Т. В. Лисоколенко, С. А. Довгаль // Науково-теоретичний альманах «Грані». - 2019. - Т. 22. - № 6. - С. 56-68.

Citation: Buturlina, O.V., Lysokolenko, T.V., \& Dovgal, S.A. (2019). Osoblyvosti rozrobky protsedurnoho planu dlia analizu dyskursu musulman v ukrainskii presi [Features of the development of a research plan for Muslims discourse analysis of the Ukrainian press]. Scientific and theoretical almanac «Grani», 22 (6), 56-68. 